\title{
The Role of Native Weaknesses and Cultural Conflicts in Escalating Colonial Supremacy in the Igbo Society, as Perceived in Arrow of God by Chinua Achebe
}

\author{
Momtajul Islam ${ }^{1}$ \\ ${ }^{1}$ King Abdulaziz University, Jeddah, Saudi Arabia \\ Correspondence: Dr. Momtajul Islam, Building 77, 3253 Alharith Alqaba Street, Al Nasim District, Jeddah 23234, \\ Saudi Arabia. E-mail: tazislam@gmail.com
}

Received: April 1, 2021; Accepted: April 27, 2021; Published: April 27, 2021

\begin{abstract}
The colonial invaders and their repressive means of governance in Africa were not the only reasons that could be solely held accountable for the fall of indigenous African society during the colonial invasion. Native weaknesses, socio-cultural conflicts and hegemony were equally responsible for the falling apart of native social setups when confronted with colonial alternatives. Native people had had their own covert religious and cultural limitations long before the colonizers entered their soil. The colonial powers cleverly used such inherent societal flaws of African people as excuses to impose European religion and traditions on them. Chinua Achebe does not blindly idealize native African traditions in his writings. He frequently narrates his doubts on flawed socio-cultural practices and moral dualities in the native society, too. This paper is an attempt to explore how innate weaknesses of native Igbo people, socio-cultural conflicts and domination in the native society have also made it easier for the colonial administration to prolong their supremacy in the Igbo land, as depicted in Arrow of God by Chinua Achebe. It also elaborates how Ezeulu, the chief priest of god Ulu, falls from dominance in his society because of his intent to execute personal desires which jeopardize his societal role in the Igbo land.
\end{abstract}

Keywords: Postcolonial literature, Chinua Achebe, native weaknesses, colonial conflicts, Arrow of God, hegemony

\section{Introduction}

This paper is an attempt to examine how some distinctive factors of colonial ascendancy including prevalent weaknesses of native people, different layers of cultural conflicts and cultural dominance of colonial forces helped in the establishment of colonial rule in the African continent as reflected in Chinua Achebe's one of the most famous novels of the colonial period. Achebe, one of the most extensively read African writers in English around the world, attempts to raise awareness against the misrepresentation of African natives and their social lives in the Western narrative through his writings. He examines the indelible impact of colonial onslaughts and the cultural dominance of Western colonial forces on African soils from the perspective of a native African. This subject of cultural conflict and colonial dominance has turned out to be crucial milieus in most of his fictional works. His distinction as an extraordinary African storyteller rests steadily on his five novels on colonial and postcolonial narrative, which are - Things Fall Apart (1958), No Longer at Ease (1960), Arrow of God (1964), A Man of the People (1966) and Anthills of the Savannah (1987), in addition to several literary lectures, poems, essays and short stories.

Cultural hegemony is often described as a form of supremacy of ruling classes on the mass through political, religious, social or cultural norms. This kind of hegemony has frequently been employed to imply the "...political dominance, usually of one state over another" (Williams 144) since the $19^{\text {th }}$ century. Antonio Gramsci, one of the pioneers of the theory of cultural hegemony, is of the view that it is a form of supremacy exerted by a dominant class, through which a subordinate or dominant section of the society, "consent to their own domination by ruling classes, as opposed to being simply forced or coerced into accepting inferior positions" (qtd. in Mastroianni). He believes that this sort of social supremacy is realized by controlling every stratum of society through social or ideological means to satisfy the interests of the ruling classes. It fundamentally refers to a privileged section of a society who acquires the power to hold control over the masses, influences the indigenous beliefs, principles, and behaviour of the social institutions. This is attained by guiding the principles, ideals and values of a society. Gramsci's sense of hegemony is roughly based on Marxist characteristics regarding how the hegemony 
of the ruling class "...can affect our day-to-day undertakings as well as our perceptions" (Rich, "Cultural Hegemony."). Instances of this type of hegemony are prevalent in this novel.

Achebe's strong desire to be an unprejudiced commentator on African traditions and cultural norms in his writings has made him a distinctive postcolonial author. Bhardwaj's comments that Achebe in his novels "writes about Igbo life as an insider and dispassionately mirrors the strengths and weaknesses of the Igbo traditional society" (118), is quite apt in this context. It was not merely the colonial rulers and their oppressive outlooks towards Africans that could be solely held responsible for the downfall of native society during colonization. Therefore, this paper is an attempt to explore how native weaknesses, widespread cultural conflicts and dominance by a privileged section of indigenous people in the native society have also made it easier for the colonial powers to perpetuate their colonial domination in this region, as represented in Arrow of God by Chinua Achebe.

\section{Native Flaws and the Emergence of African Middle-Class}

The weaknesses in native African society and its traditions, for example, the belief of native people in the presence of supernatural forces in the native society and religion also made it easier for Christian missionaries to further persuade the underprivileged natives and institute Christianity in this area. It would not be an overstatement to say that missionary invasion in the region noticeably changed Igbo social and religious structure as current social outcasts in the native society found a better alternative where they were promised to be treated equally with other Christians. During the age of colonization in Africa, several social elements including alien religions were accepted and adopted after adding numerous native socio-cultural elements to them by the colonized people to make such unfamiliar cultures and religions more relevant in their social context. Although being introduced from the Western world, foreign religions, like Christianity in this context, cannot be simply labelled as merely an invading malice that instigated African Igbo people to vehemently fight against each other. In fact, Christianity was not the only cause, responsible for the gradual annihilation of the native cultural norms and religion.

Pratten's examination of a possible reason for religious colonization in Africa is worth mentioning here. He indicates that the preexisting social chaos and lack of understanding between native youth and older generation paved the way for religious conversion in colonial Nigeria.

Pre-colonial Nigerian social structure had many different "societies" inside a society. Every native was required to be part of these different societies during different stages of his life. For instance, the society of elders was in charge of carrying out legal proceedings of the village and thus enjoyed an exclusive power to govern the village people. However, in the native social setup, native youth and the downgraded sections of the indigenous Igbo society, for instance, mothers of twins, were not inducted in any of these societies before the colonial invasion. Such sidelined people of the native society found a seemingly better alternative in Christianity as they were told not to be considered unwanted anymore in this new religion. "Colonialism and Christianity had created a rift between youth and elders and between varied bases of political authority" (Pratten, p. 93).

African society had had its own religious and cultural flaws long before the invasion of this land by the colonialists. The colonial intruders only used such native flaws cleverly to enforce Western religion and customs on the colonized native society. It is also important to mention here that Achebe does not unquestioningly romanticize native African culture and traditions in his writings. He rather expresses his doubts on the flawed native practices and moral dualities prevalent in Africa during the colonial period more often than not. His narration of young and innocent Ikemefuna's killing to exalt ill-practices in Igbo society in his masterpiece Things Fall Apart (43) is a worthy example of this notion. Simon Gikandi, a critic on Chinua Achebe, is of the view that Achebe usually examines native African social and cultural practices at the time of colonial onslaught in terms of pre-existent inner contradictions or ambivalence and does not simply applaud it as an "unquestioned authority" (xii) when confronted with alien socio-cultural forces.

Achebe writes about the shortcomings of the native society from time to time and his novels of colonial period attempt to tell readers that everything was not undeniably fine in native socio-cultural practices. In his essay "Role of the Writer in a New Nation" Achebe admits, "We cannot pretend that our past was one long, technicolour idyll. We have to admit that like other people's past ours had its good as well as its bad sides" (qtd. in Vempala 35). Also, Anthony Daniels in one of his articles observes that Achebe has no qualms about exploring the imperfections of Igbo society in his novels. "In spare prose of great elegance, without any technical distractions, he (Achebe) has been able to illuminate two emotionally irreconcilable facets of modern African life: the humiliations visited on Africans by colonialism, and the utter moral worthlessness of what replaced colonial rule" (31). Achebe neither blindly romanticizes the native social practices before the invasion of colonialism, nor does he consider the colonial experience as merely traumatic, devoid of any sort of positive bearings. 
The novel Arrow of God illustrates how Igbo cultural norms and ethnicity succumb to the Western way of life after the intrusion of colonial forces in the native socio-political and religious space. The novelist here sets out to write the colonial encounter from a colonized native's perspective using the language of the British colonial force so as to let the world know the other side of the colonial experience more vividly, unlike the erstwhile Western writers who have so far treated the colonies and their people as mere crowd devoid of any individuality. Ezeulu in this novel happens to be the chief priest of god Ulu of Umuaro clan. He yearns to be recognized as the only authority in the native religious matters so that his village people become his sincere followers, and at the same time he wishes to be revered by the British colonial administrators as an esteemed local. But he fails miserably in the process and his ambition to control both his village society and the impact of colonial invasion on his clan brings his eventual disgrace from his social status. An individual's ambition ends up being nothing more than an unfulfilled longing against the wish of his society. Mordaunt relevantly interprets that this novel "shows that men cannot fight societies' will and that the latter can bring a man to insanity" (153). Ezeulu's tragedy in Arrow of God is not simply a personal disgrace. It is a rather absolute repression of the Igbo religious and socio-cultural norms as the colonial influences have increasingly started to engulf all layers of native distinctiveness.

Another worth mentioning native trend during the colonial period is the emergence of a new native middle-class during colonization and its effect on the suppression of native Igbo society. A discrete section of native people was consciously created and employed by colonial rulers to help them control the colonies according to colonial desires and interests. This section of people was nothing more than puppets in the hands of colonial rulers and a divisive feeling was instilled in them that those who worked for the colonial powers were more privileged in comparison to the rest of the native people, as they could communicate in colonizers' languages. Fanon in his book Black Skin White Masks explains that this group of native people during colonization considered themselves as "elevated above his jungle status in proportion to his adoption of the mother country's cultural standards" (9). He continues to explain the narrow mindset of this newly formed native middle-class:

He becomes whiter as he renounces his blackness, his jungle. In the French colonial army, and particularly in the Senegalese regiments, the black officers serve first of all as interpreters. They are used to convey the master's orders to their fellows, and they too enjoy a certain position of honor.

This elevated social status of a section of native people functioned as an undercurrent that worked as an impetus in the subjugation of indigenous cultural uniqueness and ultimately helping in establishing the superiority and domination of languages and socio-cultural norms of colonial powers.

\section{Displeasure with Each Other}

The struggle of the native Igbo people in this novel is not merely limited to safeguard own cultural and religious practices from colonial invasion in their society. Colonizers and their practices in Igbo land further instigated native people to become enemies of their countrymen. Subsequently, victims of this enmity, in general, were either the new native converts or those Igbo people who still clung to indigenous religion and traditions. An instance from Achebe's landmark novel Things Fall Apart is worth referencing here. The outrageous unmasking incident of an egwugwu, the ancestral spirits of Umuofia clan, by Enoch (Achebe, Things Fall Apart 130) and the subsequent destructive attack on Enoch's house and the community church by indigenous Igbo people are consequences of lack of respect for each other's traditional and religious practices.

The conflict in Arrow of God, in terms of religious and cultural rivalry, is also between the new native Igbo Christians and indigenous Igbo people who are trying to retain the inherent religion and customs alive. These new native Christians are given a freehand by colonial forces to overpower other indigenous people in their community who were once their family and friends. Therefore, the native people of Igbo land now have to safeguard their innate socio-cultural uniqueness more from these new Igbo Christians than from the colonial outsiders. The introduction of Christianity in Igbo land also works as a divisive component to break the unity of native people, so that the Westerners could conquer and govern this area without any significant difficulties.

The Colonizers applied the 'divide and rule' strategy from time to time to colonize the native people of Africa. The Igbo society in Arrow of God is no exception either. In this novel, the self-esteem of local people of Umuaro is considerably compromised when the colonial administration compels them to do manual work for road construction without any payments. However, the people of the neighbouring village Okperi are remunerated fairly for the same work. This act of the colonial administration gives rise to some serious doubts among the natives of Umuaro. Following is the description of this incident.

...This white man thinks we are foolish; so we shall ask him one question. This was the question I had wanted to ask him this morning but he would not listen. We have a saying that a man may refuse to do what is asked of him but he may not refuse to be asked, but it seems the white man does not have that 
kind of saying where he comes from. Anyhow the question which we shall beg Unachukwu to ask him is why we are not paid for working on his road. I have heard that throughout Olu and Igbo, wherever people do this kind of work the white man pays them. Why should our own be different?" ...

'The message is not complete,' said Nwoye Udora. 'It is not enough to ask him why we are not paid. He knows why and we know why. He knows that in Okperi those who do this kind of work are paid. Therefore the question you should ask him is this: Others are paid for this work; why are we not paid? Or is our own different? It is important to ask whether our own is different."

This was agreed and the meeting broke up.

'Your words were very good,' someone said to Nwoye Udora as they left the marketplace. 'Perhaps the white man will tell us whether we killed his father or his mother.' (Achebe, Arrow of God 87-88)

It can be inferred from the above passage that the colonial settlers appear to have some covert purposes behind such discrimination, which is dividing the Igbo people in order to rule the native land effortlessly. Such acts of discrimination would add fuel to the hatred and vengeance among two clans, namely Okperi and Umuaro, which are not at good terms with each other anymore. This sort of enmity among native societies has only aided the colonial motives to establish their rules in the Igbo land with ease.

\section{Cultural Conflict and Cultural Hegemony in the Native Society and its People}

The ancestral traditions and principles of the Igbo people have started to disintegrate themselves to the changing situations with the colonial invasion. This transition has gradually begun in the Igbo community as the native society has decided to act as one voice to face the changing situations in the surroundings. Here, Ezeulu's worldly desires come in direct conflict with his role as the chief priest that he must execute in his society. Ezeulu suffers from poor eyesight which makes him worried that he may slowly go blind. So, he contemplates that "he would have to rely on someone else's eyes as his grandfather had done when his sight failed" (Achebe, Arrow of God 1). The reference here tries to indicate his fear that loss of sight could be a threat to his religious position in society. His main responsibility is to see the movement of the moon to mark the beginning of each month and if he fails to do so, his religious jurisdiction and political accountability in his society will be in danger. It is because of this huge public responsibility that his individual benefits and wishes should not become burdens in executing his societal role.

It is only when Ezeulu decides to follow his materialistic desire as an individualist, he oversteps the restrictions set by his society which are collective in nature. This becomes a fundamental conflict between the native society as a whole and Ezeulu who wants to run the society as an individual without giving much importance to the native voices in his community. Ezeulu's role as a priest is quite precise in Umuaro community. The types of commands that he can execute now are very limited like, announcing the start of a new month. When Ezeulu declines to announce the beginning of Yam festival, the elder people of his community have the following interaction with him:

'No, you are Umuaro,' said Ezeulu.

'Yes, we are Umuaro. Therefore listen to what I am going to say. Umuaro is now asking you to go and eat those remaining yams today and name the day of the harvest. Do you hear me well? I said go and eat those yams today, not tomorrow; and if Ulu says we have committed an abomination let it be on the heads of the ten of us here.' (Achebe, Arrow of God 210)

In this context, Mordaunt pertinently observes that "The apex of his conflict is reached when he refuses to eat the holy yams, thus bringing his vengeance upon all his people; even the innocent, those who are helpless, have to suffer" (158). In addition to Ezeulu's consistent inner conflict, it is also his negation in accepting the voice of other community people that leads him to his disgrace in his society. Cook relevantly infers that this novel "searches into the limits of individual power in a system controlled by tradition," (18). It is the internal disorientation of his psychological limits, instigated by external elements, that leads him to lose his dominance inside his household as well as the native society at large. The eventual breakdown of the protagonist of this novel is vividly summarized here:

So in the end only Umuaro and its leaders saw the final outcome. To them the issue was simple. Their god had taken sides with them against his headstrong and ambitious priest and thus upheld the wisdom of their ancestors that no man however great was greater than his people; that no one ever won judgement against his clan. (Achebe, Arrow of God 232) 
Ezeulu's self-centeredness has prompted the collapse of not only himself and Igbo people in particular, but also of the erstwhile Igbo religious and social uniqueness in general.

Subsequently, by the end of this novel, he fails to sustain his social stature in a world of confusion and chaos, created after the colonial invasion of Igbo land. All other conflicts in this novel arise to validate and support the basic inner conflict of the protagonist and Igbo society so that the narrative could continue to flourish effortlessly. Ezeulu's dilemma is multidimensional. While he must fight against the fast-approaching colonial religion and cultural norms, he also has to defend his exclusive social privilege of being the chief priest of god Ulu of Umuaro clan from his rivals. Ezeulu's main rival is Nwaka in Umuaro villages. He is a valuable ally of the chief priest of the god Idemili who was once ousted by the god Ulu and now Nwaka wants to reinstate Ezidemili, the chief priest of Idemili, by expelling Ezeulu. This social enmity between Ezeulu and Nwaka instigates internal division within the native ethnic group (Killam 61). Ezeulu fails to garner the support of his own people at the gathering of the community elders regarding the looming war between neighbouring clans Okperi and Umuaro over a piece of land. Rather, it is his rival Nwaka whose dissection of Ezeulu's speech gets the approval of the community people. "Nwaka inevitably becomes the voice of the tribe since the chief priest's words no longer carry any weight" (Mordaunt 159). It would not be an overstatement to note here that colonialism is not the only reason that could be held responsible for the suppression of Igbo culture and religion by colonial forces. The initial elements of the socio-cultural downfall lied much deeper inside the social fabric of Igbo people which came into the fore when confronted by the colonial culture and religion. Igbo society witnessed the rivalry between local gods including Ulu and Idemili much before the colonial invasion of the native land.

In this novel, Ezeulu is a representative of his native religious and cultural practices and in addition to his inner conflicts, he is also in distress because of his conflict with his adversaries in his community. This novel explicitly elaborates how Ezeulu tries to stay relevant in the spiritual sphere of his society when his social status is severely threatened by his rivals from his society who wants to usurp Ezeulu's religious authority.

Ezeulu's fate in this novel is a tragic one in nature. Tragic because he could not spend his life according to his own will, as he has certain social responsibilities to perform being the chief priest of Ulu. Whether he accepts it wholeheartedly or not, his god is the creation of his native Igbo community and the people of this community enjoy the power to decide whether to replace their god again if needed. Once Ezeulu overlooks this fact of his native setup, he is destined to face a sad end. "Paradoxically," as Palmer appropriately describes, "Ezeulu, who should have been the champion of his people's faith, becomes the agent of destruction" (98).

\section{Conclusion}

The novel Arrow of God recounts the decline of native ethnic philosophy, traditions and social beliefs when confronted with the European cultural alternatives after the colonial invasion. There is no denying that this novel represents the colonial hegemony and cultural conflicts in the Igbo society with the advent of colonial rule in this land. However, it is not merely the conflicts between native the Igbo cultural practices, traditions and religion, and those of the colonizers that should be held responsible as the main reasons for the establishment of the colonial hegemony in the Igbo region. Different layers of prevalent native weaknesses like socio-cultural conflicts, personal desires of privileged native people and hostility against certain sections of Igbo society before the advent of colonial powers in this region also appear to be equally responsible for the downfall of Igbo society when confronted with the dominant colonial forces. For example, the protagonist Ezeulu in this novel has been chosen by native people as a priest and not someone who can enjoy any earthly powers. But his desire to become allpowerful religious leader in his native society by further controlling both his indigenous people and influencing the advent of colonial forces, results his subsequent failure in this novel. "There is also the conflict between Ezeulu's religious power and the earthly powers of society represented by its members and furthermore there is the internal religious conflict within Ezeulu himself" (Mordaunt, pp. 168-169).

It is apparent that this novel Arrow of God primarily revolves around the theme of individual and societal native Igbo weaknesses during the colonial experience. It also portrays the cultural conflicts within traditional African societies. Indigenous pre-existing societal flaws and conflicts within different strata of native social setups were also reasonably responsible for the falling apart of the indigenous society when came in contact with the colonial counterparts. The people of Africa already had had their unique spiritual and ethical limitations present in their societies before the colonial forces invaded their land. The colonizers astutely exploited such pre-existent societal imperfections of the native people as a means to establish Christianity and Western customs on them as evident in the novel in discussion. Moreover, Chinua Achebe does not unreasonably glorify all native African socio-cultural practices in his novels. He rather puts forward his critique on some flawed socio-cultural norms and ethical dualities in native society more often than not and Arrow of God is an apt example when analysed. It is also evident 
in this novel that the inherent societal flaws of Igbo people, their cultural conflicts and hegemony have also made it less difficult for the colonial rulers to ascertain their domination in the Igbo land.

\section{References}

Achebe, C. (2010). Arrow of God. Penguin.

Achebe, C. (2010). No Longer at Ease. Penguin.

Achebe, C. (1996). Things Fall Apart. Heinemann Educational.

Cook, D. (1977). African Literature: A Critical View. Longman.

Bhardwaj, P. (Dec. 2014). "Competitive Facet of Women Dynamism in Anthills of the Savannah." International Journal of Humanities \& Social Studies, 2(12), 118-126., Retreived from http://internationaljournalcorner.com/index.php/theijhss/article/view/140778/99093.

Daniels, A. (Sept. 1987). Succumbing to an Inferior Complexity. The Spectator Archive, The Spectator, 26. http://archive.spectator.co.uk/article/26th-september-1987/31/succumbing-to-an-inferior-complexity

Gikandi, S. (1996). China Achebe and the Invention of African Literature. Things Fall Apart, by Chinua Achebe, Heinemann Educational, pp. ix-xvii.

Killam, G. D. (1977). The Writings of Chinua Achebe. Heinemann Educational.

Mordaunt, O. G. (1989). "Conflict and Its Manifestations in Achebe's 'Arrow of God."” Afrika Focus, 5(3-4), 153174. https://doi.org/10.21825/af.v5i3-4.6478

Mastroianni, D. (May 2018). Hegemony in Gramsci. Postcolonial Studies, 2. http://scholarblogs.emory.edu/postcolonialstudies/2014/06/20/hegemony-in-gramsci/

Palmer, E. (1979). The Growth of the African Novel. Heinemann Educational.

Pratten, D. (2007). The Man-Leopard Murders: History and Society in Colonial Nigeria. First ed., Indiana University Press. https://doi.org/10.3366/edinburgh/9780748625536.001.0001

Rich, T. (May 2016). Cultural Hegemony. Thomas Rich Blog, 5. http://rampages.us/richtm/2016/05/05/culturalhegemony/

Vempala, J. L. R. (2015). Culture and Anarchy in the Novels of Chinua Achebe. Prakash Book Depot, 2003.Williams, Raymond. Keywords: A Vocabulary of Culture and Society. Revised Edition ed., Oxford University Press.

\section{Copyrights}

Copyright for this article is retained by the author(s), with first publication rights granted to the journal.

This is an open-access article distributed under the terms and conditions of the Creative Commons Attribution license (http://creativecommons.org/licenses/by/4.0/). 